\title{
Woven Structures from Natural Fibres for Reinforcing Composites
}

\author{
Aina Bernava ${ }^{1}$, Maris Manins ${ }^{2}$, Guntis Strazds ${ }^{3}$, \\ ${ }^{1,3}$ Forest Industry Competence Centre, ${ }^{2}$ Riga Technical University
}

\begin{abstract}
The increase of production of woven structures from natural fibres for reinforced composites can be noticed in different sectors of economy. This can be explained by limited sources of raw materials and different environmental issues, as well as European Union guidelines for car manufacture [4]. This research produced 2D textile structures of hemp yarn and polypropylene yarn and tested the impact of added glass fibre yarn on the mechanical properties of the woven structures and the composites produced from them. The woven structures were manufactured using hand looms or industrial looms (CTL-175) using one layer technique. The mechanical testing of the reinforcements showed that the parameters of the looms had significant impact on the properties of the reinforcements. However, the desired improvement of strength by adding glass fibre to the fabric was not achieved. The one, two, three and four layer composites were produced in a hydraulic press using reinforcements woven from hemp yarn and polypropylene yarn. The mechanical testing of composites showed that the tensile strength of the composites and the tensile stress at maximum load depends on number of the reinforcement layers, but the tensile extension of the composites and the modulus of elasticity are not closely related to the number of reinforcement layers, but rather on elasticity of yarn used in weaving. Swelling of composites in water was detected.
\end{abstract}

Keywords - Natural fibre, woven reinforcement, hemp yarns, flax yarns.

\section{INTRODUCTION}

The use of natural fibres as a replacement for traditional glass fibre in composites has gained an increasing importance in the recent years as environmental concerns have led to a quest for sustainable alternatives. The interest in natural fibrereinforced polymer composite materials is rapidly growing in industrial applications and in fundamental research. They are renewable, cheap, completely or partially recyclable, and biodegradable [1]. Natural fibre reinforced composites are found in countless consumer products including boats, skis, agricultural machinery and cars. The largest advantages of using natural fibres in composites are the cost of materials, their sustainability and density [2]. The natural fibre component uses $45 \%$ less energy and results in lower air pollution emissions [3]. Many companies, such as Mercedes Benz, Toyota and Daimler Chrysler, are already using these and are looking to expand the uses of natural fibre composites [4]. In the European Union (EU) $80000 \mathrm{t}$ of natural fibre composites for the automotive industry in 2012 year were produced and $5 \%$ of the total volume was with hemp fibre [5].

The forecast for EU in 2020 is 3.2 million tonnes of natural fibre composites, including bio-composites $(920000 \mathrm{t})$ and plastics reinforced with natural fibres for construction, furniture, automotive, consumer goods (100000 t), are planned to be produced [3]. The chemical, mechanical, and physical properties of natural fibres have distinct properties. It depends on the cellulosic content of the fibres, which varies from fibre to fibre. The mechanical properties of composites are influenced mainly by the adhesion between matrix and fibres [6]. Mechanical properties have limitations for their mechanical properties, particularly with regard to impact resistance [7].

Natural fibre composites are used to manufacture components of car interiors and truck cabins, because this reduces weight by about $10 \%$, energy production by $80 \%$ and costs by $5 \%$. Typical market specification for natural fibre composites include elongation and ultimate breaking forces, flexural properties, strength on impact, acoustic absorption, suitability for processing and crash behaviour [8].

This work is focused on comparing mechanical properties of woven reinforcements and reinforced composites depending on the production methods, as well as on the use of composite production reinforced with woven hemp yarn and polypropylene yarn.

\section{MATERIALS AND METHODS}

\section{A. Materials and Technique of Production}

The hemp yarn (HA) with the yarn density 100 tex, glass fibre yarn (136 tex) and polypropylene (PP) yarn with the yarn density 100 tex were used to produce four types of reinforcement:

1. The fabric from hemp yarn $(100 \%)$ on both directions was produced using an industrial loom СТБ-175. This fabric was used to ascertain the influence of weaving method on mechanical properties of reinforcement.

All other fabrics were made using a craftsman's loom.

2. Hemp yarn fabric $(100 \%)$ on both directions.

3. Hemp yarn fabric with added glass fibre yarn mass fraction $25 \%$ on the warp direction (a one in four hemp yarn threads is replaced with glass fibre yarn thread). The weft threads are of hemp yarn.

The fabrics of $2^{\text {nd }}$ and $3^{\text {rd }}$ groups were used as basis for modelling the next two groups of reinforcements $\left(4^{\text {th }}\right.$ and $\left.5^{\text {th }}\right)$.

4. Fabric built up from hemp yarn (mass fraction $38 \%$ ) and polypropylene yarn (mass fraction 62\%) on both directions (each warp and weft thread consists of both yarns). 
5. The fabric built up from hemp yarn (mass fraction $44 \%$ ), polypropylene yarn (49\%) and glass fibre yarn $(7 \%)$ on both directions (in the warp direction hemp and polypropylene yarn are reduplicated, in the weft glass fibre yarn and polypropylene yarn].

Hemp yarn and glass fibre yarn were tested according to standard LVS EN ISO 5079:2001 before weaving. Results of mechanical tests for 100 tex hemp showed that the tensile strength was $15.47 \mathrm{~N}$ and the tensile extension was $3.4 \%$, while for glass fibre yarn the tensile strength was 6.3 times higher, but the tensile extension was 1.2 times lower (Table I).

TABLE I

YARNS USED AND PHYSICAL-MECHANICAL PROPERTIES

\begin{tabular}{|c|c|c|c|}
\hline & $\begin{array}{c}\text { Yarn } \\
\text { density, tex }\end{array}$ & $\begin{array}{c}\text { Tensile } \\
\text { strength, } \mathrm{N}\end{array}$ & $\begin{array}{c}\text { Tensile } \\
\text { extension, \% }\end{array}$ \\
\hline Hemp fibre yarn(HA) & 100 & 15.46 & 3.46 \\
\hline Glass fibre yarn (GF) & 136 & 97.44 & 2.85 \\
\hline $\begin{array}{c}\text { Polypropylene fibre } \\
\text { yarn (PP) }\end{array}$ & 100 & - & - \\
\hline
\end{tabular}

\section{B. Methods for Quality Testing}

The determination of maximum force and elongation at maximum force, using the strip method (corresponding to the standard LVS EN ISO 13934-1-2001) were used for the warp direction of reinforcements on INSTRON dynamometer. The fabric thickness was measured according to the standard ISO 5084:1996 and the fabric surface density was calculated according to the standard LVS EN 12127:2001 for all reinforcement samples.

TABLE II

PARAMETERS OF REINFORCEMENTS

\begin{tabular}{|l|c|c|c|c|c|}
\hline & $\begin{array}{c}\text { HA, } \\
\text { indus- } \\
\text { trial }\end{array}$ & $\begin{array}{c}\text { HA, } \\
\text { hand } \\
\text { made }\end{array}$ & $\begin{array}{c}\text { HA/ } \\
\text { GF }\end{array}$ & $\begin{array}{c}\text { HA/ } \\
\text { PP }\end{array}$ & $\begin{array}{c}\text { HA/ } \\
\text { PP/ } \\
\text { GF }\end{array}$ \\
\hline Fabric thickness, mm & 0.61 & 0.69 & 0.94 & 1.20 & 1.10 \\
\hline Surface density, $\mathrm{g} / \mathrm{m}^{2}$ & 91 & 100 & 99 & 340 & 250 \\
\hline & \multicolumn{5}{|c|}{ Threads, dm } \\
\hline Warp direction & 50 & 50 & 48 & 100 & 100 \\
\hline Weft direction & 42 & 55 & 46 & 228 & 144 \\
\hline & \multicolumn{5}{|c|}{ Used yarns, \% (mass fraction) } \\
\hline HA & 100 & 100 & 83 & 38 & 44 \\
\hline GF & & & 17 & & 7 \\
\hline PP & & & & 62 & 49 \\
\hline
\end{tabular}

The average surface density (Table II) of $1^{\text {st }}$ and $2^{\text {nd }}$ group reinforcements of hemp yarn was $91 \mathrm{~g} / \mathrm{m}^{2}$ for industrially made reinforcement and $100 \mathrm{~g} / \mathrm{m}^{2}$ for hand-made reinforcement and thickness of the fabrics were $0.61 \mathrm{~mm}$ and $0.69 \mathrm{~mm}$, respectively. The same parameters for $3^{\text {rd }}$ group reinforcement of hemp yarn and glass fibre yarn on warp direction (mass fraction 17\%) and for hemp yarn on weft direction same parameters were $0.94 \mathrm{~mm}$ and $99 \mathrm{~g} / \mathrm{m}^{2}$ $(\mathrm{HA} / \mathrm{GF})$. For $1^{\text {st }}$ and $2^{\text {nd }}$ group samples on the warp direction there were $48-50$ threads $(\mathrm{dm})$, while on the weft direction there were $42-55$ threads $(\mathrm{dm})$.
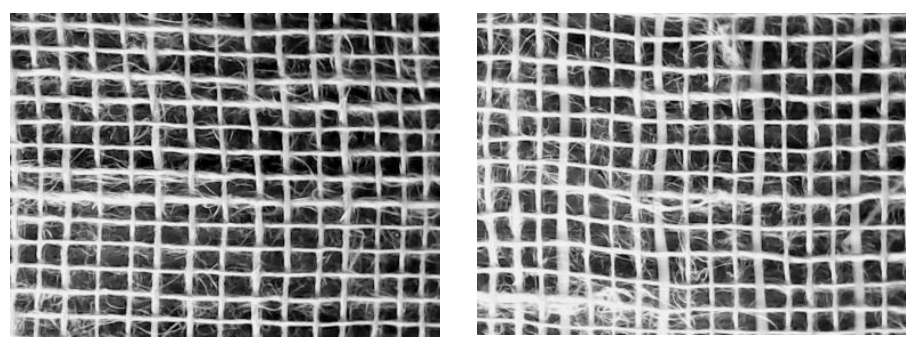

Fig. 1. Reinforcement from hemp yarn (left), hemp and glass fibre yarn (right), size $\sim 35 \mathrm{~mm} \times 25 \mathrm{~mm}$.

\section{Processing of the Composites}

To process composites the $4^{\text {nd }}$ group reinforcements of hemp yarn and polypropylene yarn with the surface density $340 \mathrm{~g} / \mathrm{m}^{2}$ and $1.2 \mathrm{~mm}$ thickness of as well as $5^{\text {th }}$ group reinforcement of hemp yarn, polypropylene yarn and glass fibre yarn on both directions with surface density $250 \mathrm{~g} / \mathrm{m}^{2}$ and thickness $1.10 \mathrm{~mm}$ were used (Table II). The density of the warp threads $1 \mathrm{dm}$ was 100 yarns while the weft thread density $1 \mathrm{dm}$ was 144 yarns (HA/GF/PP) and 228 yarns (HA/PP).

TABLE III

REINFORCEMENTS USED FOR COMPOSITE PRODUCTION AND COMPOSITES SURFACE PARAMETERS

\begin{tabular}{|c|c|c|c|c|}
\hline \multicolumn{2}{|c|}{ Reinforcement use } & \multicolumn{3}{c|}{ Composite } \\
\hline HA/PP & HA/GF/PP & $\begin{array}{c}\text { Desig- } \\
\text { nation }\end{array}$ & $\begin{array}{c}\text { Thickness, } \\
\text { mm }\end{array}$ & $\begin{array}{c}\text { Density, } \\
\mathrm{g} / \mathrm{m}^{2}\end{array}$ \\
\hline 1 & & C_1 & 0.34 & 311 \\
\hline 2 & 1 & C_2 & 0.59 & 608 \\
\hline 1 & 1 & C_3 & 0.59 & 480 \\
\hline 2 & & C_4 & 0.90 & 840 \\
\hline 3 & 2 & C_5 & 0.90 & 880 \\
\hline 2 & & C_6 & 1.10 & 1040 \\
\hline
\end{tabular}

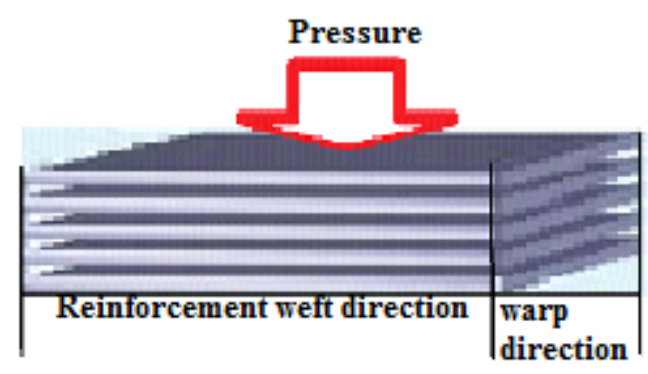

Fig. 2. Composite processing method.

To form composites reinforcement layer-up method and compression moulding (hydraulic press LP-S-50, ASTM LabTech Engineering Co., Ltd.) at temperature $190^{\circ} \mathrm{C}$ was used. Preheating time was $10 \mathrm{~s}$ for composites (C_1, C_2, C_3 and C_4) to form, or $180 \mathrm{~s}$ and contact + cooling time $360 \mathrm{~s}$ to form composites (C_5 and C_6). The composite processing methods and parameters used for reinforcements can be seen in Fig. 2 and Table II. All layers of reinforcements (from 2 to 4) were put one on the other without changing warp/weft directions. 


\section{Composite Testing}

Tensile properties of fibre-reinforced plastic composites were tested for the warp direction, according to ISO 5275:2009 standard, using an INSTRON dynamometer (Fig. 5 to Fig. 8). The composites thickness after swelling in water (TS) was measured according to EN 622-2: 2004 standard (Fig. 9).

\section{RESULTS AND DISCUSSION}

TABLE IV

MECHANICAL PROPERTIES OF REINFORCEMENTS

\begin{tabular}{|c|c|c|c|c|c|}
\hline & \multicolumn{2}{|c|}{ HA } & \multirow{2}{*}{$\begin{array}{l}\mathrm{HA} / \\
\mathrm{GF}\end{array}$} & \multirow{2}{*}{$\begin{array}{l}\mathrm{HA} / \\
\mathrm{PP}\end{array}$} & \multirow{2}{*}{$\begin{array}{l}\mathrm{HA} / \\
\mathrm{PP} / \\
\mathrm{GF}\end{array}$} \\
\hline & industrial & $\begin{array}{l}\text { hand- } \\
\text { made }\end{array}$ & & & \\
\hline $\begin{array}{l}\text { Tensile } \\
\text { strength, N }\end{array}$ & 279.8 & 241.7 & 318.9 & 1098.2 & 1032.6 \\
\hline $\begin{array}{l}\text { Tensile } \\
\text { extension, \% }\end{array}$ & 2.56 & 2.60 & 2.95 & 17.2 & 15.0 \\
\hline $\begin{array}{l}\text { Tensile stress } \\
\text { at maximum } \\
\text { load, } \mathrm{MPa}\end{array}$ & 6.75 & 6.93 & 6.78 & 25.84 & 18.77 \\
\hline $\begin{array}{l}\text { Modulus of } \\
\text { elasticity, } \\
\mathrm{MPa}\end{array}$ & 294.34 & 271.24 & 229.56 & - & - \\
\hline
\end{tabular}

The tensile strength of industrially woven hemp reinforcement (Table IV, Fig. 1) was about $14 \%$ higher than that of a handmade reinforcement, because threads on craftsman's loom were more stretched and injured in weaving process. The value of modulus of elasticity was about $8 \%$ higher for industrially made reinforcement, while the tensile stress at maximum load (Table III) was about $3 \%$ higher for handmade reinforcement.

The increase of mechanical strength (Table IV), which is about $13 \%$, was achieved by adding of glass fibre yarn on the warp direction, while the modulus of elasticity is about $23 \%$ lower than the modulus of elasticity for industrially made reinforcement of hemp yarn. The tensile extension for hemp yarn reinforcements is $2.56 \%-2.60 \%$, while for the hemp/glass fibre yarn reinforcements the increase was about $14 \%$, due to damage of glass fibre from hemp yarn in the weaving process.

The $4^{\text {th }}$ and $5^{\text {th }}$ group of hemp, polypropylene and glass fibre yarn reinforcements cannot be considered as reinforcement only, but also as base materials for the manufacture of composite, where polypropylene yarn will act as composite matrix. As it can seen in Table IV, the tensile strength $(1098.2 \mathrm{~N})$ and tensile stress at maximum load $(25.84 \mathrm{MPa})$ as well as tensile extension $17.2 \%$ are about $75 \%$ higher than for industrially made reinforcement of hemp yarn and it was ensured by the use of polypropylene yarn. The tensile strength of HA/PP fabric (Fig. 3) was large (1121.5 N), but it was gained from the strength of PP yarn. The hemp yarn loses its strength at $500-600 \mathrm{~N}$. With addition of glass fibre ( $7 \%$ mass fraction) for $5^{\text {th }}$ group of reinforcements the mechanical improvement was not achieved, due to warp yarn density in a reed and the damage of glass fibre yarn in the weaving process (Table IV).

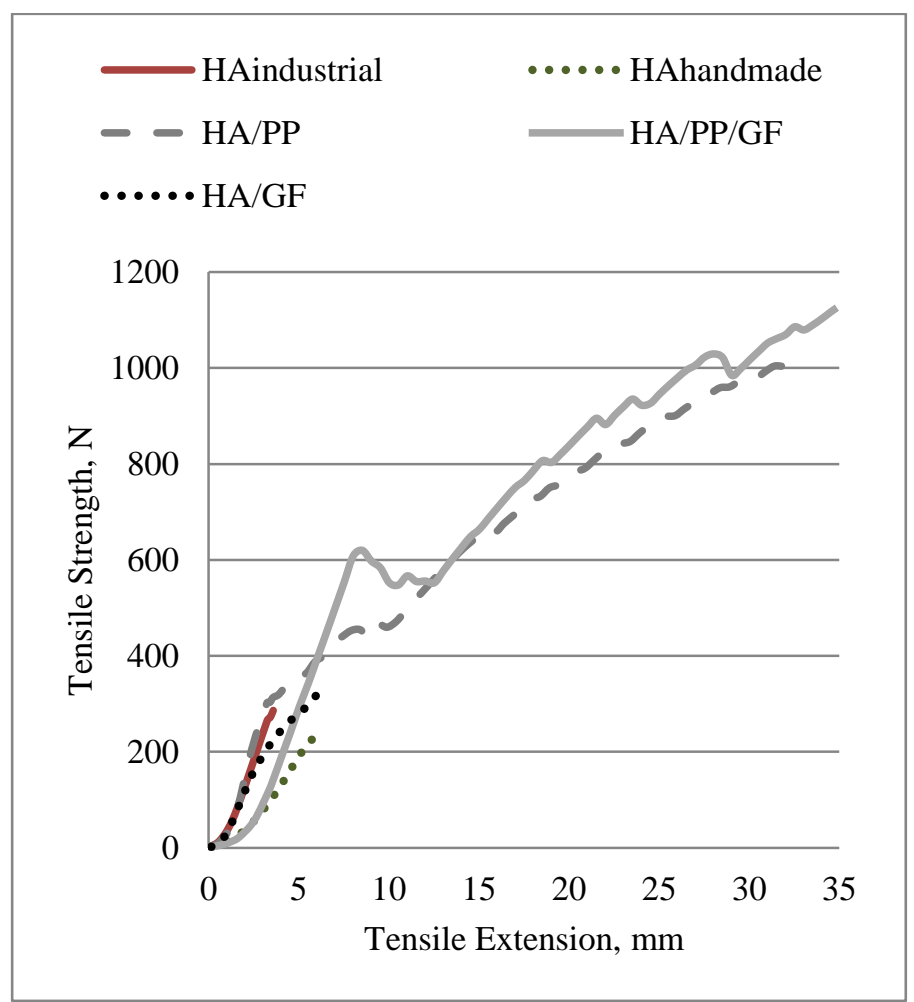

Fig. 3. Tensile strength and tensile extension of woven fabrics.
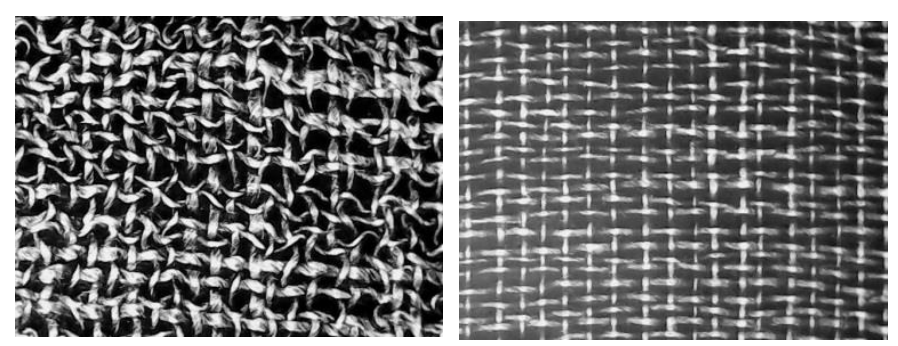

Fig. 4. Pictures of composite $C_{-} 1$ (left) and composite C_3 (right).

The picture (Fig. 4, left) shows, that the reinforcement structure in the composite is flinched with preheating time $180 \mathrm{~s}$, due to plasticity of PP. The reduction of preheating time to $10 \mathrm{~s}$ eliminated the deformation of matrix (Fig. 4, right) and the results of testing showed the performance of composite.

By comparing of the surface parameters of the reinforcements used and the produced composites (Table II and Table III) it can be seen that:

- The thickness of one layer composite was 3.5 times lower and the density of composite was 1.1 times lower, if the same parameters were used for reinforcement.

- The two layer composite was 4 times thinner and the density of composite was about $1.1-1.2$ times lower than for two reinforcements used for production of the composite.

- The tree layer composite was about 4 times thinner and the density of composite was about 1.1 times lower than for three reinforcements used for production of the composite.

- The four layer composite was 4.2 times thinner and density of the composite is 1.1 times lower than for reinforcements used for production of the composite. 
The thickness of reinforcement was about 3.5-4.2 times and density of composite was $1.1-1.2$ times higher as the same parameters of produced composites. This was connected with the process of threads squeezing during pressing and loss of moisture during cooling.

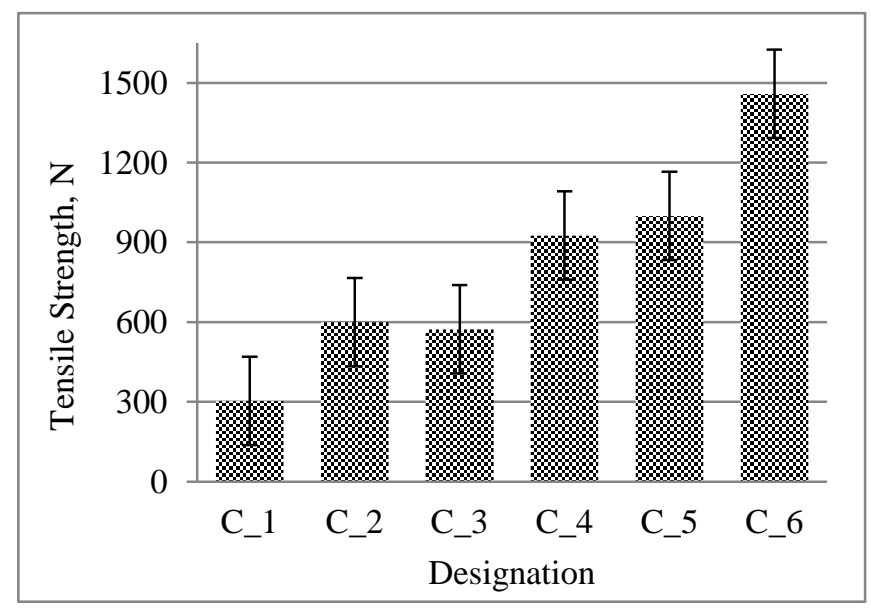

Fig. 5. Tensile strength of the composites.

The tensile strength of the composites (Fig. 5) varied from $303.09 \mathrm{~N}$ to $1459.0 \mathrm{~N}$, depending on building parameters of the composite. The tensile strength of one, two and three layer composites was $1.1-1.2$ higher than for three layer composite (C_4) and four layer composite (C_5) the values were $1.1-1.3$ times lower as for reinforcements used for production. For two and three layer composites the higher tensile strength was for composite with PP (62\% mass fraction). The increase of tensile strength with the addition of glass fibre yarn (7\% mass fraction) was not observed.

The tensile extension of composites were higher 1.5-2.6 times (Fig. 6) than for used reinforcements (Table IV) and varied from $3.53 \%$ to $4.62 \%$ depending on the used reinforcements layers. The increase of tensile extension with scale-up layers was observed and pointed towards tensile extension of PP matrix.

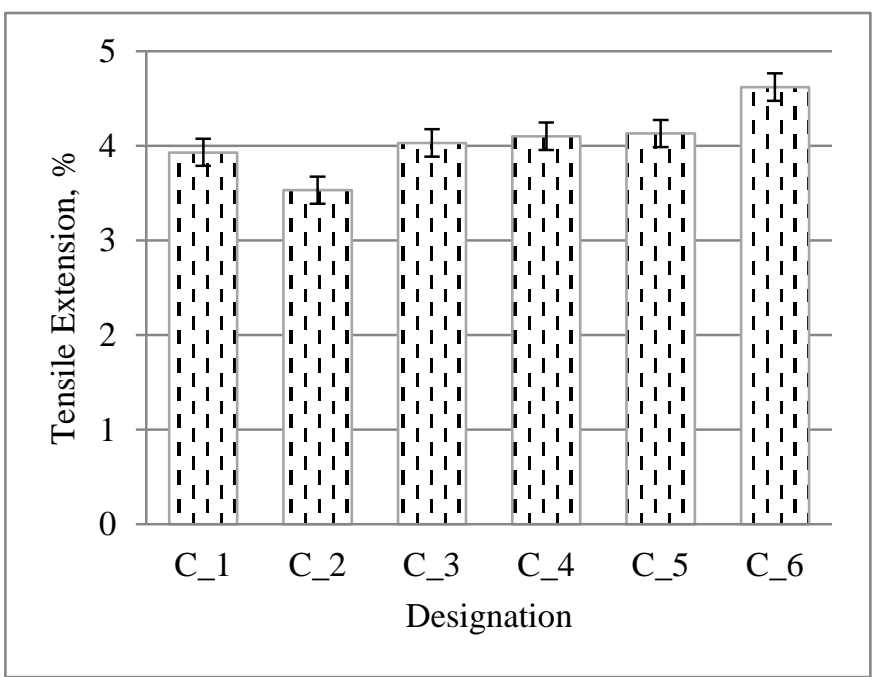

Fig. 6. Tensile extension of composites.

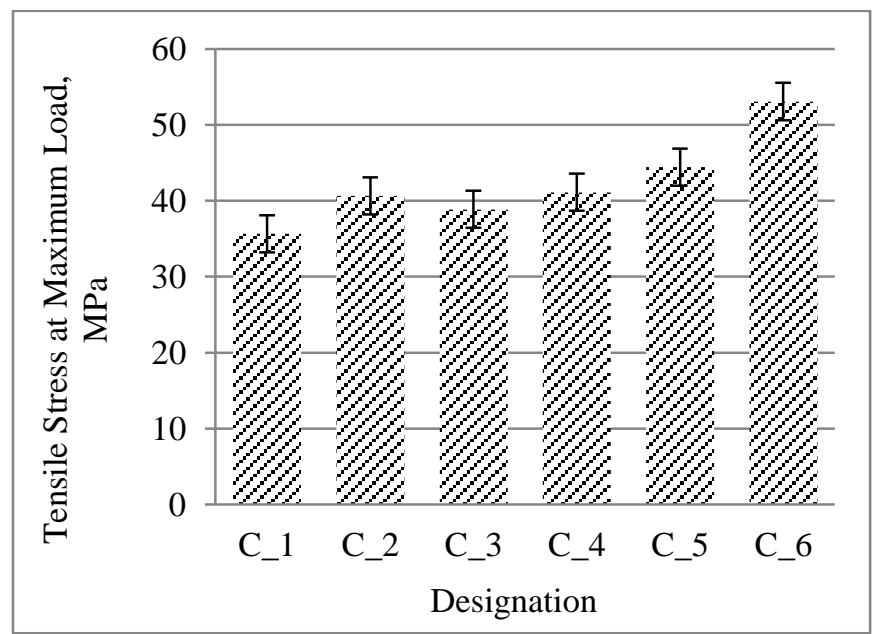

Fig. 7. Tensile stress of composites at maximum load.

The increase of tensile stress of composites at maximum load for 2 times was observed (Fig. 7) with reduction of preheating time in case of one layer composite. Meanwhile, the influence of layer number ( 2 or 3 ) on the value of tensile stress at maximum load yielded about $9 \%-13 \%$ and $17 \%$ in case of 4 layers, when compared to the previous layer. For one layer composites the tensile stress at maximum load was 5.2 times higher; $2.9-3$ times higher for two layer composites; 2.2 times higher for three layer composites and 1.9 times higher for four layer composites than for reinforcements used for production of composites.

The higher modulus of elasticity (Fig. 8) is for composites of two layers (C_2) and four layer composite (C_6). While for two layer composite (C_3) modulus of elasticity is 1.19 times lower, also it pointed out the influence of PP maxtrix quantity in composite. The modulus of elasticity was 3.4 times higher for one layer composite; 2.1-1.9 times for two layer composite; $1.2-1.3$ times for three layers composite and 1.1 times for four layer composite, than for used reinforcement.

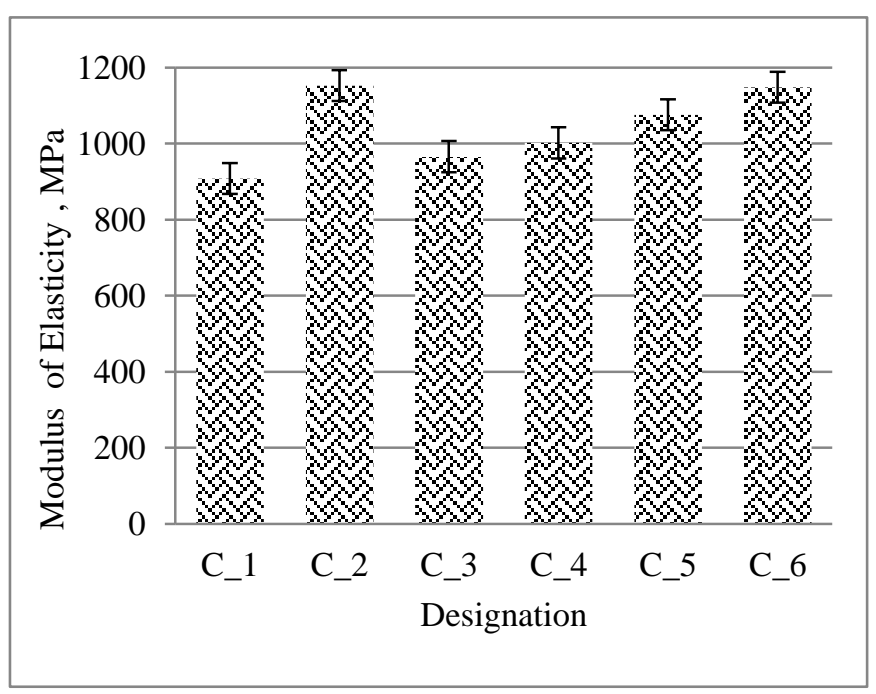

Fig. 8. Modulus of elasticity of composites. 


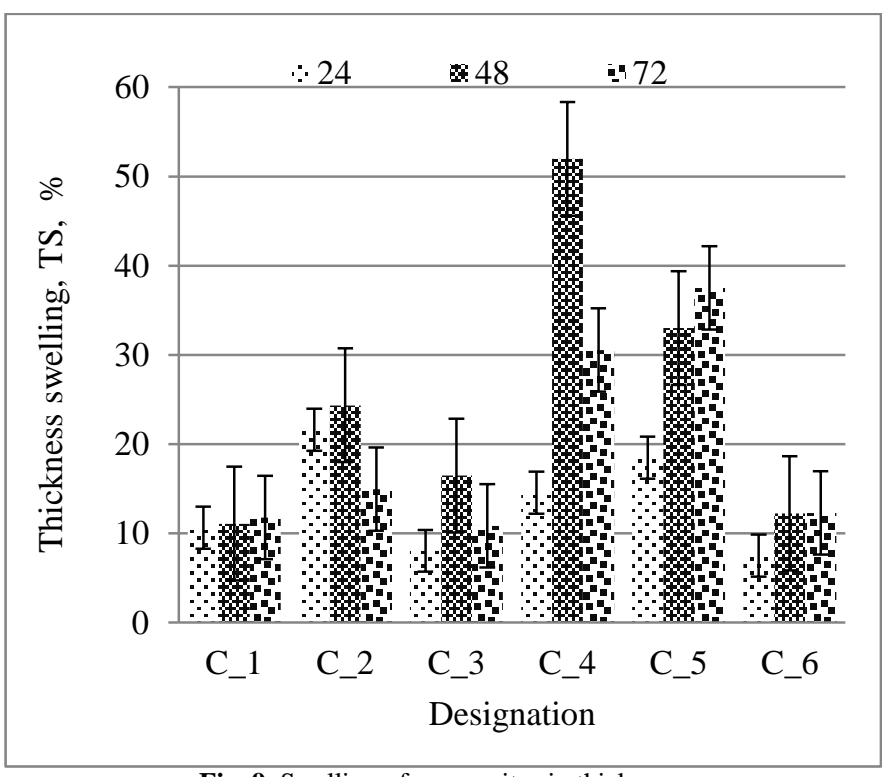

Fig. 9. Swelling of composites in thickness.

Immersion in water caused the change of thickness for all composites (Fig. 9). The lowest thickness change was $7.5 \%$ for four layer composite (C_6) after $24 \mathrm{~h}$ testing, while at the same time for two layer composite (C_2) the thickness swelling is 2.9 times higher. After $48 \mathrm{~h}$ testing the highest thickness change $(34.2 \%)$ was for three layer composite (C_4), the lowest thickness change $(11.1 \%)$ was for one layer composite. At the end of testing $(72 \mathrm{~h})$ the thickness swelling of the composites was from $11.8 \%\left(C_{-} 1\right)$ to $37.5 \%$ (C_5). For this reason the impact of certain factors on changes of composite thickness upon immersion in water depend on the quantity of natural fibres in the composite.

\section{CONCLUSION}

Technical textiles based on composites are rapidly developing in the range of light-weight engineering materials. 2D woven structures depending on application and composite processing were executed in plain weaving technique. Investigation of production methods for woven fabric structures showed strong impact on mechanical properties the tensile strength, the tensile stress at maximum load and the tensile extension, as well as the modulus of elasticity of reinforcements. Composite mechanical testing showed that the composite tensile strength and the tensile stress at maximum load were dependent on the number of reinforcement layers, but the tensile extension of composites and the modulus of elasticity were not closely related to the number of composite layers, but to the elasticity properties of used fibres and the composite production method. For this reason the thickness changes of composite upon immersion in water can be detected and the thickness change depends on the quantity of natural fibres in the composite.

\section{ACKNOWLEDGMENT}

The authors would like to thank the Director of Riga Technical University Institute of Polymer Materials
Dr. J. Zicans and the staff for their support in the development of the composites.

\section{REFERENCES}

1. Singh A., Vishvendra M.S., Study of Mechanical Properties of Hybrid Natural Fiber Composites. A Thesis for degree of Bachelor of Technology In Mechanical Engineering, Department of Mechanical Engineering National Institute of Technology Rourkela, 2011.

2. Westman M.P., Fifield L.S., Kafentzis T.A., Laddha S.G., Simmons K.L., Natural Fiber Composites: A Review, Pacific Northwest National Laboratory, 2010. http://dx.doi.org/10.2172/989448

3. Joshi S.V., Drzal L.T., Mohanty A.K., Arora S., Are natural fiber composites environmentally superior to glass fiber reinforced composites? Comp.Part A, vol. 35, 2004, pp. 371-376. http://dx.doi.org/10.1016/j.compositesa.2003.09.016

4. Holbery J., Houston D., Natural-Fiber-Reinforced Polymer Composites in Automotive Applications, Materials, Design and Manufactoring for Lightweight Verhicles, Woodhed Publishing Ltd, 2010, pp. 235-306.

5. Carus M. World-wide Market Data on Hemp and Other Bast Fibres, Presentation of 11th EIHA Conference Wesseling, 21.05 2014, Rewiev 19, 06. 2014.

6. Ramakrisha M., Kurmar V., Singh Y.N., Recent Development in Natural Fibre reinforced Polypropylene composites, Journal of Reinforced Plastics and Composites, vol. 28, 2009, pp. 1169-1189. http://dx.doi.org/10.1177/0731684407087759

7. Shahzad A., Isaac D.H. and Alston S.M., Mechanical Properties of Hemp Fibre Composites, http://compositesuk.co.uk/ Rewiev 07.10. 2014.

8. Jamrichova Z., Akova E., Mechanical Testing of Natural Fibre Composites for Automotive Industry, University Review 2013, vol. 7, no. 3, 20-25.

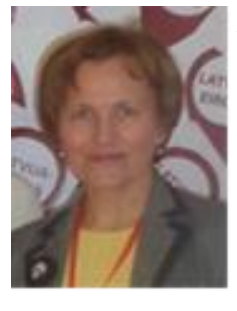

Aina Bernava has a professional master's degree in Materials Design and Technology, Riga Technical

University, Institute of Textile Materials Technologies and Design (2011). She is a master in the Latvian Chamber of Crafts since 2004.

Since 2007 she was a scientific assistant in Riga Technical University, Institute of Polymer Materials (since 2007). She has worked as a researcher in the ESF project "Establishment of interdisciplinary research groups for new, functional properties of

Smart textiles, development and integrating in innovative products" between 2009 and 2012. She also is a contractor in the project "Investigation of Latvian renewable raw materials - flax and hemp products for development of innovative technologies and new functional materials" in 2012 and in MNKC- LIAA Project of Natural Fibers and Flax Fibers Property's (since 2013).

E-mail: aina.bernava@inbox.lv

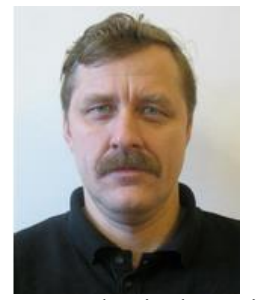

Maris Manins has a professional Master Degree in Material Design and Technology, Riga Technical University, Institute of Textile Materials Technologies and Design (2009). He is a doctoral student at Riga Technikal Univesity, Institute of Design and Technologies since 2009. He works as a designer for LZKU,,Klippan-Saule since 2000

He has worked as a researcher for scientific projects in Riga Technical University since 2009. He was a Researcher in the project "Establishment of interdisciplinary research groups for a new functional properties of smart textiles development and integrating in innovative products" from 2009 to 2012.

From 2010 to 2013 he was a researcher in the project "Investigation of Latvian renewable raw materials - flax and hemp products for development of innovative technologies and new functional materials." E-mail: maris.manins@rtu.lv 


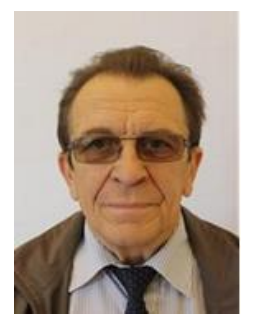

Guntis Strazds is a production engineer specializing in Fibre Material Technologies, Riga Technical University since 1965 and St. Petersburg Institute of Textiles. He holds a Dr. habil. sc. ing. degree in textile technology since 1989 . He is the president of the Textile and Garment Industry Association of Latvia since1994. He is a council member of Valmiera Glass Fibre company since 1997. He was an Expert for Enterprise Europe Network Latvia from 2012 to 2014.
He was the leading researcher in ESF project "Establishment of interdisciplinary research groups for a new functional properties of smart textiles development and integrating in innovative products" from 2009 to 2012. He was the head of the project "Investigation of Latvian renewable raw materials: flax and hemp products for development of innovative technologies and new functional materials" from 2010 to 2013.

Since 2012 he is a researcher in Ltd. MNKC- LIAA Project of Natural Fibers and Flax Fibers Properties.

E-mail: stragu@latnet.lv

\section{Aina Bernava, Māris Maniņš, Guntis Strazds, Austas dabisko šķiedru struktūras kompozītu armēšanai}

Tautsaimniecībā ir pieaugusi ar dabiskām šķiedrām armētu kompozītu materiālu ražošana. Pēc 2012. gada Eiropas Rūpniecisko Kaņepju Asociācijas (EIHA) datiem ar dabiskām šḳiedrām stiegrotus kompozītus izgatavoja $80000 \mathrm{t}$ apjomā, bet 2020. gadā plānots saražot 3.2 miljonus t. Šāds dabisko šķiedru kompozītu ražošanas pieaugums ir saistīts ar ierobežotajiem izejvielu resursiem un dabas aizsardzības jautājumiem, kā arī ar Eiropas Savien̄ibas vadlīnijām auto ražotājiem. Šajā pētījumā izstrādātas 2D austas struktūras no kaņepju pavedieniem, polipropilēna pavedieniem, kā arī pārbaudīta stikla šksiedras pavedienu pievienošanas ietekme uz austu struktūru un, no to izgatavoto kompozītu materiālām, mehāniskajām īpašībām. Austās struktūras izstrādātas rokas aužamajās un rūpnieciskajās $(C T 5-175)$ stellēs audekla tehnikā. Armatūru mehāniskās testēšanas rezultātu analīze parāda, ka steḷıu parametri būtiski ietekmē armatūru īpašības, stiprība rūpnieciski izgatavotajai armatūrai ir par 14 \% lielāka kā rokas aužamajās stellēs izgatavotajai armatūrai. Aizvietojot 25 \% kaņepāju auduma pamatnes ar stikla šķiedras pavedieniem, auduma stiprība pieaug par $13 \%$. Kompozītu formēšanai izmantotas kaņepāju/polipropilēna pavedienu armatūras, klājot tās vienā, divās, trīs vai četrās kārtās un presējot hidrauliskajā presē 10 min $190{ }^{\circ} \mathrm{C}$ temperatūrā. Izgatavoto kompozītu biezums ir 3.5 - 4 reizes mazāks nekā ieklāto armatūru biezums. Kompozītu mehāniskās testēšanas rezultāti norāda, ka kompozītu stiprība un stiepes spriegums pieaug proporcionāli armatūru kārtu skaitam. Elastība stiepē kompozītiem ir 1.5 - 2.6 reizes lielāka nekā kaņepāju armatūrām. Kompozīta elastības modulis nav cieši saistīts ar kompozītā ieklāto armatūru kārtu skaitu, bet gan ar aušanā izmantoto šķiedru elastības īpašībām. Pēc 72 stundu pārbaudes ūdens vidē kompozītu biezums pieauga par $11.8 \%-37.5 \%$, atkarībā no ieklāto armatūru kārtu skaita un tas saistīts ar kaņepāju šķiedru hidroskopiskumu.

\section{Айна Бернава, Марис Маныньш, Гунтис Страздс. Тканые структуры из натуральных волокон для армирования композитных материалов.}

Во многих секторах народного хозяйства повышается уровень использования композитных материалов на базе натуральных волокон. По данным Европейской Ассоциации промышленной конопли (ЕІНА), в 2012 году было произведено 8000 тонн композитных материалов из натуральных волокон, а в 2020 году планируется произвести 3,2 миллиона тонн. Это связано с ограниченными ресурсами сырья и вопросами охраны окружающей среды, а также с руководящими принципами Европейского Союза для автомобильной промышленности. В исследовании разработаны тканые структуры 2 и из нитей конопли и полипропилена, а также проверено влияние добавленных нитей стекловолокна на физико-механические свойства тканых структур и композитов. Тканые структуры производятся на ручных и промышленных (СТБ-175) ткацких станках в полотняном переплетении. Результаты механических тестов показывают, что ткацкий станок значительно влияет на свойства арматуры. Разрывная прочность ткани, сотканной на промышленном станке, на 14 \% выше. Достигается 13-процентное улучшение прочности на разрыв при замене 25 \% пряжи конопли на нити по основе стекловолокна. Композитные материалы изготавливаются в гидравлическом прессе из одного, двух, трех и четырех слоев тканых материалов из нитей конопли и полипропилена в течение 10 минут при температуре $190{ }^{\circ} \mathrm{C}$. Результаты механического тестирования композитных материалов показывают, что прочность и растягивающее напряжение зависят от количества слоев тканых материалов, но эластичность и модуль упругости при растяжении композитных материалов не связаны с числом слоев, а зависят от используемых волокон в тканом материале. При тестировании в водяной ванне (72 часа) констатированы изменения толщины композита на 11,8 \% - 37,5 \% . 